\section{Commentary: London Bridge is falling down - how will we build it up?}

\author{
Les James, MD, MPH, and Eugene A. Grossi, MD
}

In this review by Pausch and colleagues, ${ }^{1}$ supplemental repair techniques for functional mitral regurgitation (MR) are summarized. The authors tout papillary muscle relocation as a valid adjunct to downsizing annuloplasty, particularly with its immediate echocardiographic benefits in controlling leaflet tethering. However, as in the infamous nursery rhyme "London Bridge Is Falling Down," we may be able to build the mitral complex up with "stone so strong will last so long"- -but the question is how long?

The 2016 randomized controlled clinical trial by Nappi and colleagues ${ }^{2,3}$ compared patients with severe ischemic mitral regurgitation (IMR) who underwent coronary artery bypass grafting revascularization with either combined papillary muscle approximation (PMA) and restrictive annuloplasty (RA) or undersized valve repair alone. Preoperative left ventricular end-diastolic diameter was $62.7 \pm 3.4 \mathrm{~mm}$ in the PMA group and $61.4 \pm 3.7 \mathrm{~mm}$ in the RA group. While PMA demonstrated significant improvement in left ventricular end-diastolic diameter during follow-up, there was no statistically significant difference in clinical outcomes. Importantly, this study observed a high rate of MR recurrence in both groups: $55.9 \%$ for RA and $27 \%$ for PMA.

These findings beg the question: in which subset of patients with MR is papillary muscle relocation appropriate? The 2014 Cardiothoracic Surgical Trials Network trial

From the Department of Cardiothoracic Surgery, NYU Grossman School of Medicine, New York, NY.

Disclosures: Dr Grossi has intellectual property and receives royalties from Medtronic for valve repair devices and has intellectual property and receives royalties from Edwards Lifesciences. Dr James reported no conflicts of interest.

The Journal policy requires editors and reviewers to disclose conflicts of interest and to decline handling or reviewing manuscripts for which they may have a conflict of interest. The editors and reviewers of this article have no conflicts of interest.

Received for publication Sept 20, 2021; revisions received Sept 20, 2021; accepted for publication Sept 24, 2021; available ahead of print Sept 28, 2021.

Address for reprints: Eugene A. Grossi, MD, Department of Cardiothoracic Surgery,

NYU Grossman School of Medicine, 530 First Ave, Suite 9V, Skirball Building,

New York, NY 10016 (E-mail: Eugene.Grossi@nyulangone.org).

JTCVS Techniques 2021;10:98-9

2666-2507

Copyright (C 2021 The Author(s). Published by Elsevier Inc. on behalf of The American Association for Thoracic Surgery. This is an open access article under the CC BY-NC-ND license (http://creativecommons.org/licenses/by-nc-nd/4.0/).

https://doi.org/10.1016/j.xjtc.2021.09.043

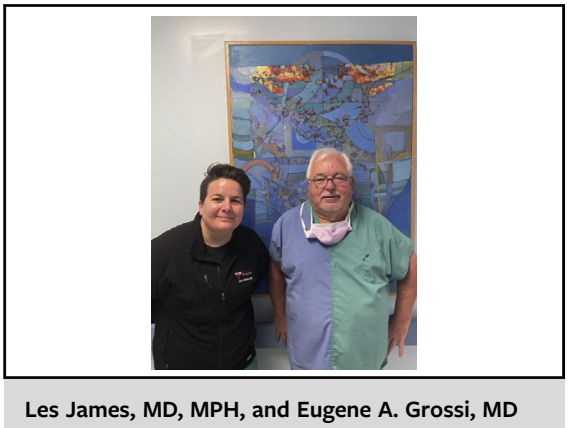

CENTRAL MESSAGE

Supplemental repair strategies

for FMR, including papillary

muscle relocation, are valuable

adjuncts to downsizing annulo-

plasty; however, durability for

different size ventricles remains

in question.

randomly assigned patients with severe IMR to either repair or chordal-sparing replacement to evaluate efficacy and safety. ${ }^{4}$ While there was no survival difference, ominously, at 2 years, the rate of recurrence of moderate or severe MR was $58.8 \%$ in the repair group (vs $3.8 \%$ in the replacement group, $P<.001)^{5}$

A subset analysis by Capoulade and colleagues ${ }^{6}$ of the 2 Cardiothoracic Surgical Trials Network trials on patients with IMR who received MV repair demonstrated that left ventricular end-systolic dimension was significantly greater in patients with recurrent MR (48 \pm 8 vs $45 \pm 9 \mathrm{~mm}$; $P=.01)$. In univariate analysis, patients with large ventricle size after MR were predicted to have 1-year recurrent MR after ring annuloplasty (odds ratio per 10-mm increase, $1.62 ; 95 \%$ confidence interval, $1.09-2.40 ; P=.02){ }^{6}$ This re-echoes the data from Braun and reinforces that the $\mathrm{LV}$ ultimately holds the fate of the repaired valve.

Which ventricles benefit from relocating the papillary muscles or performing other adjunct techniques to prevent recurrent MR is yet unknown. Whether functional mitral repair with subannular repair strategies is durable enough to "last so long, last so long," only time will tell.

\section{References}

1. Pausch J, Girdauskas E, Conradi L, Reichenspurner H. Secondary mitral regurgitation repair techniques and outcomes: subannular repair techniques in 
secondary mitral regurgitation type IIIb. J Thorac Cardiovasc Surg Tech. 2021;10: 92-7.

2. Nappi F, Lusini M, Spadaccio C, Nenna A, Covino E, Acar C, et al. Papillary muscle approximation versus restrictive annuloplasty alone for severe ischemic mitral regurgitation. J Am Coll Cardiol. 2016;67:2334-46.

3. Nappi F, Spadaccio C, Chello M, Mihos CG. Papillary muscle approximation in mitral valve repair for secondary MR. J Thorac Dis. 2017;9(suppl 7):S635-9.

4. Acker MA, Parides MK, Perrault LP, Moskowitz AJ, Gelijns AC, Voisine P, et al. Mitral-valve repair versus replacement for severe ischemic mitral regurgitation. N Engl J Med. 2014;370:23-32.
5. Goldstein D, Moskowitz AJ, Gelijns AC, Ailawadi G, Parides MK, Perrault LP et al. Two-year outcomes of surgical treatment of severe ischemic mitral regurgitation. N Engl J Med. 2016;374:344-53.

6. Capoulade R, Zeng X, Overbey JR, Ailawadi G, Alexander JH, Ascheim D, et al. Impact of left ventricular to mitral valve ring mismatch on recurrent ischemic mitral regurgitation after ring annuloplasty. Circulation. 2016;134: 1247-56.

7. Braun J, van de Veire NR, Klautz RJ, Versteegh MI, Holman ER, Westenberg JJ, et al. Restrictive mitral annuloplasty cures ischemic mitral regurgitation and heart failure. Ann Thorac Surg. 2008;85:430-6; discussion 436-7. 